\title{
Comparison of Apolipoprotein E Polymorphism and other Atherosclerotic Risk Factors in two Portuguese Populations - the Influence of Insularity
}

\author{
Paula Alexandra Lopes ${ }^{1}$, Gisela Gaspar ${ }^{2}$, Patrícia Napoleão ${ }^{1}$, Maria Cristina Santos ${ }^{3}$, \\ Maria Leonor Pavão ${ }^{4}$ and Ana Maria Viegas-Crespo ${ }^{1}$ * \\ ${ }^{1}$ Centro de Biologia Ambiental and Departamento de Biologia Animal; Faculdade de Ciências; Universidade de \\ Lisboa;1749-016 Lisboa - Portugal. ${ }^{2}$ Centro de Biopatologia; Laboratório de Química Clínica; Instituto Nacional \\ de Saúde Dr. Ricardo Jorge; Av. Padre Cruz, 1649-016 - Lisboa - Portugal. ${ }^{3}$ Centro de Química e Bioquímica and \\ Departamento de Química e Bioquímica; Faculdade de Ciências; Universidade de Lisboa; 1749-016 - Lisboa - \\ Portugal. ${ }^{4}$ C.I.R.N.; Universidade dos Açores; Rua Mãe de Deus, 9500-801 - Ponta Delgada - Portugal
}

\begin{abstract}
The main objective of this study was to investigate the apolipoprotein (apo) E genotypes in Portuguese populations from mainland (Lisbon city) and from San Miguel Island, Azores' Archipelago (Ponta Delgada city) and to look for differences between these particular sites in apparently healthy subjects. Also, subjects with clinical diagnosis of atherosclerotic disease were investigated in San Miguel Island. In Lisbon, the genotypes distribution was: $\varepsilon 3 / \varepsilon 3>$ $\varepsilon 3 / \varepsilon 4>\varepsilon 2 / \varepsilon 3>\varepsilon 4 / \varepsilon 4$ while that, for Ponta Delgada and regardless the health condition, was: $\varepsilon 3 / \varepsilon 3>\varepsilon 2 / \varepsilon 3>$ E3/E4. Within Ponta Delgada control group, females and males had distinct genotype frequencies. The most common atherosclerotic risk factors as body mass index, blood hypertension and serum lipid parameters, presented some differences among the allelic subgroups of apo E. The major conclusions were: 1) an apparent influence of insularity in apo E polymorphism was observed; 2) both the high risk genotypes $\varepsilon 2 / \varepsilon 2$ and $\varepsilon 2 / \varepsilon 4$ were not found, even in patients; 3) curiously, the genotypes proportion in females was not homogenous among the three groups.
\end{abstract}

Key words: Apolipoprotein E polymorphism, cardiovascular risk factors, atherosclerosis, insularity

\section{INTRODUCTION}

Apolipoprotein E (apo E), an arginine-rich glycoprotein with 299 amino acids, is an integral surface component of chylomicrons, very-low density lipoproteins (VLDL), and some subclasses of high-density lipoproteins (HDL) (Hagberg et al., 2000; Lin and Kao, 2003; Leon et al., 2004). Its primary function is as a ligand for receptormediated uptake of triglyceride-rich lipoproteins, but it also modulates the activity of several lipidmetabolizing enzymes, including lipoprotein lipase, lecithin cholesterol acyl transferase, and cholesterol ester transferase (Leon et al., 2004). In addition, it appears to be involved with reverse cholesterol transport by HDL (Mahley, 1988; Leon et al., 2004). Apo E gene expression affects (more than any other gene identified so far) the cholesterol metabolism (Eichner et al., 2002; Bhakdi, 2003) and is thought to account for about $10 \%$ of the interindividual variation in total serum cholesterol concentration (Stengard et al., 1996; Ballantyne et al., 2000). The genomic organization of apo $\mathrm{E}$ is similar to that of the apo $\mathrm{A}$ and apo $\mathrm{C}$

\footnotetext{
* Author for correspondence
} 
gene families, suggesting that these genes may share a common ancestor (Rall et al., 1982; Hagberg et al., 2000). Apolipoprotein E is primarily synthesized in the liver, but other organs and tissues are recognized to synthesize it, as brain, spleen, kidneys, gonads, adrenals, and macrophages (Mahley, 1988; Eichner et al., 2002). The structural gene locus for apo $E$ is polymorphic: 3 common alleles, $\varepsilon 2, \varepsilon 3$ and $\varepsilon 4$, code for 3 homozygous genotypes ( $\varepsilon 2 / \varepsilon 2, \varepsilon 3 / \varepsilon 3$ and $\varepsilon 4 / \varepsilon 4)$, and 3 heterozygous genotypes ( $\varepsilon 2 / \varepsilon 3$, $\varepsilon 3 / \varepsilon 4$ and $\varepsilon 2 / \varepsilon 4$ ), although other less frequent variants have been reported (Ehnholm et al., 1986; Richard et al., 1994; Yokoyama, 2004). The isoforms differ from each other by a single amino acid substitution and by their binding affinity for the four apo E receptors (Richard et al., 1994; Siest et al., 1995a). Those alleles with well known decreasing frequency are grouped into three major isoforms: apo E2 (that contains cysteine at both positions 112 and 158), apo E3 (contains cysteine at position 112 and arginine at position 158) and apo E4 (contains arginine at both positions 112 and 158) (Richard et al., 1994; Siest et al., 1995a; Braeckman et al., 1996; Ballantyne et al., 2000). The apo E gene polymorphism has also a strong prediction effect on the level of its gene products: $\varepsilon 2$ is associated with higher concentrations of apo $\mathrm{E}$ and $\varepsilon 4$ with the opposite effect (Siest et al., 1995a; Eichner et al., 2002).

The $\varepsilon 2$ allele, when present in homozygosity, is associated with type III hyperlipoproteinemia, a familial disorder characterized by hypertriglyceridemia and hypercholesterolemia (Hui et al., 1984; Mahley et al., 1984), while the $\varepsilon 4$ allele has been prospectively associated with pathological conditions, as coronary artery disease, ischemic heart disease, stroke, postoperative cognitive dysfunction and Alzheimer's disease (Roses, 1998; Vincent-Viry et al., 1998; Dreon and Peroutka, 2001; Shea et al., 2002), since promotes elevated levels of both total cholesterol and LDL-cholesterol in plasma (Mahley et al., 1984; Mahley, 1988). The most usual pathophysiological feature explaining these positive clinical associations, mainly with the $\varepsilon 4$ allele, has been proposed to be associated with decreased endogenous antioxidant capability (Peroutka and Dreon, 2000; Shea et al., 2002) and several recent studies support the hypothesis that pathological conditions mostly associated with this allele can be moderated by antioxidant therapies, such as vitamin E administration (Dreon and Peroutka, 2001). In the past, neither predictive nor diagnostic genetic testing for genes susceptibility (e.g. apolipoprotein E, apolipoprotein B) were encouraged, but in the last few years, various authors have proposed the clinical utility of individual's apo E allelic profile determination as a strategy to identify patients at high risk of some oxidative damage-associated diseases (Siest et al., 1995a; Dreon and Peroutka, 2001). The atherosclerosis is a typical case. In recent years, the apo E polymorphism has been not only associated with lipid metabolism, as previously referred but also with blood coagulation and endothelial function which are known to play an important role in atherosclerosis development (Andreassi, 2003). It is well recognized the crucial role of apo $\mathrm{E}$ in the transport of lipoproteins and thus its involvement in several arterial wall processes (Slooter et al., 2001), wherein oxidative stress conditions might be involved. The presence of functional allelic variations may determine individual's susceptibility for the manifestation of atherosclerosis, depending on the interaction with other factors such as other genes, dietary habits and/or environmental factors (Andreassi, 2003; Tan et al., 2003). In addition, metabolic factors such as obesity and blood pressure might constitute key components for premature atherosclerosis and associations with apo $\mathrm{E}$ polymorphism have been explored (de Knijff et al., 1994; Uusitupa et al., 1994; Siest et al., 1995a; Schwanke et al., 2002).

The objectives of the present study were to investigate the apo E genotype distribution in apparently healthy Portuguese subjects living in two geographically apart cities, Lisbon (mainland) and Ponta Delgada (San Miguel Island - Azores' Archipelago), in order to test the influence of insularity on genotyping variability and to study the apo E polymorphism distribution in subjects suffering from atherosclerosis disease, from Azores' Archipelago. Other purpose was to look for possible relationships between apo $\mathrm{E}$ genotypes and the gender as well as the most current cardiovascular risk factors as body mass index, hypertension and lipid profile. To the best of our knowledge, this study was the first report examining apo E polymorphism in a Portuguese island, since Lisbon population was already studied during the ApoEurope Project (Schiele et al., 2000). 


\section{SUBJECTS AND METHODS}

\section{Populations}

The healthy subjects (controls) were recruited in the National Health Institute Dr. Ricardo Jorge (Lisbon) and Atlantilab Laboratories (Ponta Delgada). Patients from Ponta Delgada with coronary heart disease submitted to percutaneous revascularization constituted the pathological group. All subjects gave their informed consent for participating in the study, which was approved by the ethics committee of the National Health Institute Dr. Ricardo Jorge. Information on health status, drug intake and smoking behaviour was obtained for each participant through a questionnaire. Smokers consumed on average 15 cigarettes per day. Both body height and weight were registered and body mass index (BMI=ratio between weight and squared height, in $\mathrm{kg} / \mathrm{m}^{2}$ ) was calculated as an index of body size used in current analyses. The World Health Organization reported the following categories for BMI: obese $(\geq 30$ $\left.\mathrm{kg} / \mathrm{m}^{2}\right)$, overweight $\left(25.0-29.9 \mathrm{~kg} / \mathrm{m}^{2}\right)$, normal $\left(18.5-24.9 \mathrm{~kg} / \mathrm{m}^{2}\right)$ and underweight $\left(<18.5 \mathrm{~kg} / \mathrm{m}^{2}\right)$ (Expert Panel, 1998). Systolic and diastolic blood pressures were measured to the nearest $\mathrm{mm} \mathrm{Hg}$. Hypertension was defined according to the recommendations of the National Institutes of Health (systolic blood pressure > $140 \mathrm{~mm} \mathrm{Hg}$ and/or diastolic blood pressure $>90 \mathrm{~mm} \mathrm{Hg}$ or under antihypertensive therapy) (Santos and Barros, 2003).

\section{Laboratory analysis \\ Blood collection}

Subjects were fasted overnight and blood samples were taken in the morning into vacutainer tubes, containing EDTA for DNA extraction and no additives for serum. For DNA extraction, samples were stored at $-70^{\circ} \mathrm{C}$ until analyses. Serum was separated after centrifugation at $1500 \mathrm{~g}$ for 10 minutes at $4^{\circ} \mathrm{C}$ and the determinations of lipids concentrations carried out at once.

\section{Lipid profile evaluation}

Separation of HDL lipoproteins was obtained by adding polyethylene glycol to the fresh samples in order to precipitate other lipoproteins (Ballantyne et al., 1982). Enzymatic methods were applied to assay total cholesterol, HDL-cholesterol and triglycerides concentrations in serum, using CHOD-PAP $^{\circledR}$, HDL-C Plus ${ }^{\circledR}$ and GPO-PAP ${ }^{\circledR}$ analysis kits, respectively (Roche Diagnostics, Manheim, Germany). LDL-cholesterol concentration was estimated by the original Friedewald formula (Friedewald et al., 1972).

\section{Apo E genotyping}

DNA extraction was performed following the method of Miller et al. (1988). Briefly, the genotyping procedure uses the Polymerase Chain Reaction (PCR) to amplify the apolipoprotein E gene sequences containing amino acid positions 112 and 158. The amplification products were then submitted to digestion with the restriction enzyme Hha I, as described elsewhere (Hixson and Vernier, 1990). Each apo E allele yields a distinct pattern after electroforesis on polyacrylamide gels (Hixson and Vernier, 1990; Richard et al., 1994).

\section{Data analysis}

The statistical analysis was performed using GenePop $3.4^{\circledR}$ and Statistica 5.0 ${ }^{\circledR}$ softwares. Apo E allele frequencies were estimated using the genecounting method and a $\chi^{2}$-goodness-of-fit test was applied to evaluate the genetic Hardy-Weinberg equilibrium (Guo and Thompson, 1992) for the apo $\mathrm{E}$ polymorphism. The differences in apo $\mathrm{E}$ allele frequencies between the study groups were tested using a $\chi^{2}$-association test. Three subgroups were created corresponding to E2-, E3- and E4containing genotypes in order to explore the allelic effect and to increase statistical power (Braeckman et al., 1996). Carriers of the $\varepsilon 2$ allele ( $\varepsilon 2 / \varepsilon 3)$ were classified as E2, homozygotes for the $\varepsilon 3$ allele $(\varepsilon 3 / \varepsilon 3)$ as E3 and carriers of the $\varepsilon 4$ allele $(\varepsilon 3 / \varepsilon 4$ and $\varepsilon 4 / \varepsilon 4)$ as E4. Subjects with the $\varepsilon 2 / \varepsilon 2$ or the $\varepsilon 2 / \varepsilon 4$ genotypes were not found in this study. Normality of the other variables was tested and since all parameters presented normal distributions, no further transformations were carried out. A t-test was performed to compare means samples, being the global level of statistical significance set at $\alpha=0.05$.

\section{RESULTS}

\section{Populations characteristics}

Table 1 reports the descriptive statistics, according to the provenience, anthropometric parameters and 
health condition. The mean age for the three groups was similar. The majority of individuals were classified as obese or overweight subjects, having the patients higher BMI values.
Hypertension occurrence was more pronounced in patients. Concerning lipid contents, no differences were found between control subjects from the two cities (Table 1).

Table 1 - Baseline characteristics for Lisbon and Ponta Delgada groups.

\begin{tabular}{|c|c|c|c|}
\hline \multirow[b]{2}{*}{ Parameters } & \multirow{2}{*}{$\begin{array}{c}\text { Lisbon } \\
\text { Control } \\
(\mathrm{n}=67)\end{array}$} & \multicolumn{2}{|c|}{ Ponta Delgada } \\
\hline & & $\begin{array}{c}\text { Control } \\
(\mathrm{n}=40)\end{array}$ & $\begin{array}{c}\text { Patients } \\
(\mathrm{n}=40)\end{array}$ \\
\hline Females (\%) & 67 & 55 & 50 \\
\hline Age (years) & $54 \pm 7$ & $51 \pm 7$ & $56 \pm 8$ \\
\hline BMI $\left(\mathrm{kg} / \mathrm{m}^{2}\right)$ & $27.3 \pm 4.7$ & $26.2 \pm 3.5$ & $30.2 \pm 4.6$ \\
\hline Systolic BP (mm Hg) & $132 \pm 21$ & $129 \pm 18$ & $146 \pm 21$ \\
\hline Diastolic BP (mm Hg) & $80 \pm 12$ & $82 \pm 13$ & $89 \pm 13$ \\
\hline Hypertension (\%) & 36 & 23 & 78 \\
\hline \multicolumn{4}{|l|}{ Serum Lipids (mg/dl) } \\
\hline Total Cholesterol & $209 \pm 37$ & $213 \pm 33$ & $192 \pm 39^{a}$ \\
\hline HDL-Cholesterol & $59 \pm 13$ & $57 \pm 13$ & $43 \pm 8^{\mathrm{a}}$ \\
\hline LDL-Cholesterol & $129 \pm 34$ & $133 \pm 32$ & $114 \pm 33^{\mathrm{a}}$ \\
\hline Triglycerides & $104 \pm 45$ & $101 \pm 36$ & $157 \pm 62^{\mathrm{a}}$ \\
\hline Hyperlipidemia (\%) & 61 & 70 & 72.5 \\
\hline Current Smoking (\%) & 3 & 42.5 & 32.5 \\
\hline \multicolumn{4}{|l|}{ Medicine intake (\%) } \\
\hline Statins & 3 & 10 & 77.5 \\
\hline Antihypertensives & 22 & 17.5 & 77.5 \\
\hline Antiplatelet agents & 1.5 & 0 & 82.5 \\
\hline
\end{tabular}

Data are presented as mean \pm standard deviation, except otherwise indicated. ${ }^{a}$ Significant differences between the patients and control groups from Ponta Delgada (t-test, $p<0.05$ ).

In Ponta Delgada, comparing serum lipids for control and patients, all parameters reached powerful statistically significance having the patients higher triglycerides and lower HDLcholesterol concentrations, in spite of lower levels of both total and LDL-cholesterol (probably due to statins treatment) (Table 1). Smokers were greatly represented in Ponta Delgada, being the accounts observed in this city identical for control and patients (Table 1). Results for lipid parameters, blood pressure and BMI were similar between smokers and nonsmokers within each group (data not shown), thus justifying no need for further division. As seen in Table 1, the high number of patients consumed drugs. Several subjects conjugated more than one therapy, being the percentages 2.5 and 4.4 for the control subjects from Ponta Delgada and Lisbon, respectively and $77 \%$ for the patients. Moreover, the conjugation of the three therapies was only observed in the pathological group (55\%). 
Table 2 - Prevalence of apo E genotypes for Lisbon and Ponta Delgada groups.

\begin{tabular}{|c|c|c|c|c|c|c|}
\hline & \multirow{2}{*}{\multicolumn{2}{|c|}{$\begin{array}{c}\text { Lisbon } \\
\text { Control }\end{array}$}} & \multicolumn{4}{|c|}{ Ponta Delgada } \\
\hline & & & \multicolumn{2}{|c|}{ Control } & \multicolumn{2}{|c|}{ Patients } \\
\hline & $\mathbf{n}$ & gender & $\mathbf{n}$ & gender & $\mathbf{n}$ & gender \\
\hline \multicolumn{7}{|c|}{ Observed frequencies } \\
\hline$\varepsilon 2 / \varepsilon 3$ & 5 & $2 \mathrm{~F} / 3 \mathrm{M}$ & 8 & $6 \mathrm{~F} / 2 \mathrm{M}$ & 5 & $1 \mathrm{~F} / 4 \mathrm{M}$ \\
\hline$\varepsilon 3 / \varepsilon 3$ & 54 & $39 \mathrm{~F} / 15 \mathrm{M}$ & 28 & $12 \mathrm{~F} / 16 \mathrm{M}$ & 31 & $18 \mathrm{~F} / 13 \mathrm{M}$ \\
\hline$\varepsilon 3 / \varepsilon 4$ & 7 & $4 \mathrm{~F} / 3 \mathrm{M}$ & 4 & $4 \mathrm{~F}$ & 4 & $1 \mathrm{~F} / 3 \mathrm{M}$ \\
\hline$\varepsilon 4 / \varepsilon 4$ & 1 & $1 \mathrm{M}$ & 0 & - & 0 & - \\
\hline$\chi^{2}$ statistic $^{\mathrm{a}}$ & \multicolumn{2}{|r|}{2.242} & \multicolumn{2}{|r|}{1.246} & \multicolumn{2}{|r|}{0.643} \\
\hline$P$-value & \multicolumn{2}{|r|}{0.326} & \multicolumn{2}{|r|}{0.536} & \multicolumn{2}{|r|}{0.725} \\
\hline \multicolumn{7}{|c|}{ Relative allele frequencies } \\
\hline$\varepsilon 2$ & \multicolumn{2}{|r|}{0.037} & \multicolumn{2}{|r|}{0.100} & \multicolumn{2}{|r|}{0.063} \\
\hline$\varepsilon 3$ & \multicolumn{2}{|r|}{0.896} & \multicolumn{2}{|r|}{0.850} & \multicolumn{2}{|r|}{0.888} \\
\hline$\varepsilon 4$ & \multicolumn{2}{|r|}{0.067} & \multicolumn{2}{|r|}{0.050} & \multicolumn{2}{|r|}{0.050} \\
\hline
\end{tabular}

${ }^{a} \chi^{2}$ : statistic between observed and expected values under Hardy-Weinberg equilibrium.

\section{Distribution of apo E genotypes}

The distribution of apo E genotypes for the three groups showed no significant departure from Hardy-Weinberg equilibrium (Table 2).

Although all three alleles were represented in the samples, both $\varepsilon 2 / \varepsilon 2$ and $\varepsilon 2 / \varepsilon 4$ genotypes were not found (as referred before) and only one male was found in Lisbon with the $\varepsilon 4 / \varepsilon 4$ genotype (Table 2). The majority of the subjects were $\varepsilon 3 / \varepsilon 3$ homozygous and the occurrence of both $\varepsilon 2 / \varepsilon 3$ and $\varepsilon 3 / \varepsilon 4$ heterozygous genotypes appeared to be inverted between Lisbon and Ponta Delgada (Table 2). For Lisbon, the largest count was for the $\varepsilon 3 / \varepsilon 3$ genotype, with the $\varepsilon 3 / \varepsilon 4$ genotype as the second largest, followed by the $\varepsilon 2 / \varepsilon 3$ genotype and lastly the $\varepsilon 4 / \varepsilon 4$ genotype (Table 2 ). For Ponta Delgada and regardless the health condition, the largest counts were for the $\varepsilon 3 / \varepsilon 3$ genotype, followed by the $\varepsilon 2 / \varepsilon 3$ genotype and finally the $\varepsilon 3 / \varepsilon 4$ genotype (Table 2). Thus, the relative allelic frequency of $\varepsilon 3$ was identical for both cities, being lower for $\varepsilon 2$ and higher for $\varepsilon 4$ in Lisbon compared to Ponta Delgada.

The apo E genotypes distribution for the Portuguese population was proved to be similar between genders $\left(\chi^{2}=2.3, \mathrm{~d} f=3, p=0.05\right)$. This trend was observed within the Lisbon $\left(\chi^{2}=4.7\right.$, $\mathrm{d} f=3, p=0.05)$ and Ponta Delgada pathological groups $\left(\chi^{2}=3.6, \mathrm{~d} f=2, p=0.05\right)$, but not in controls from Ponta Delgada $\left(\chi^{2}=6.2, \mathrm{~d} f=2, p=0.05\right)$ (Fig. 1; Table 2).

A general approach confirmed that the genotypes proportion in males was homogenous among the three groups $\left(\chi^{2}=5.7, \mathrm{~d} f=6, p=0.05\right)$. The same observation could not be applied for the female gender $\left(\chi^{2}=12.4, \mathrm{~d} f=4, p=0.05\right)$.

Distribution of body mass index, blood pressure and serum lipids, according to apo $E$ genotypes In Table 3, body mass index, systolic and diastolic blood pressures and serum lipid concentrations according to apo E genotype subgroups, are presented for Lisbon and Ponta Delgada. In controls, either from Lisbon or from Ponta Delgada, the BMI was similar, but the E3 subgroup of patients had higher BMI than its control (Table 3). 


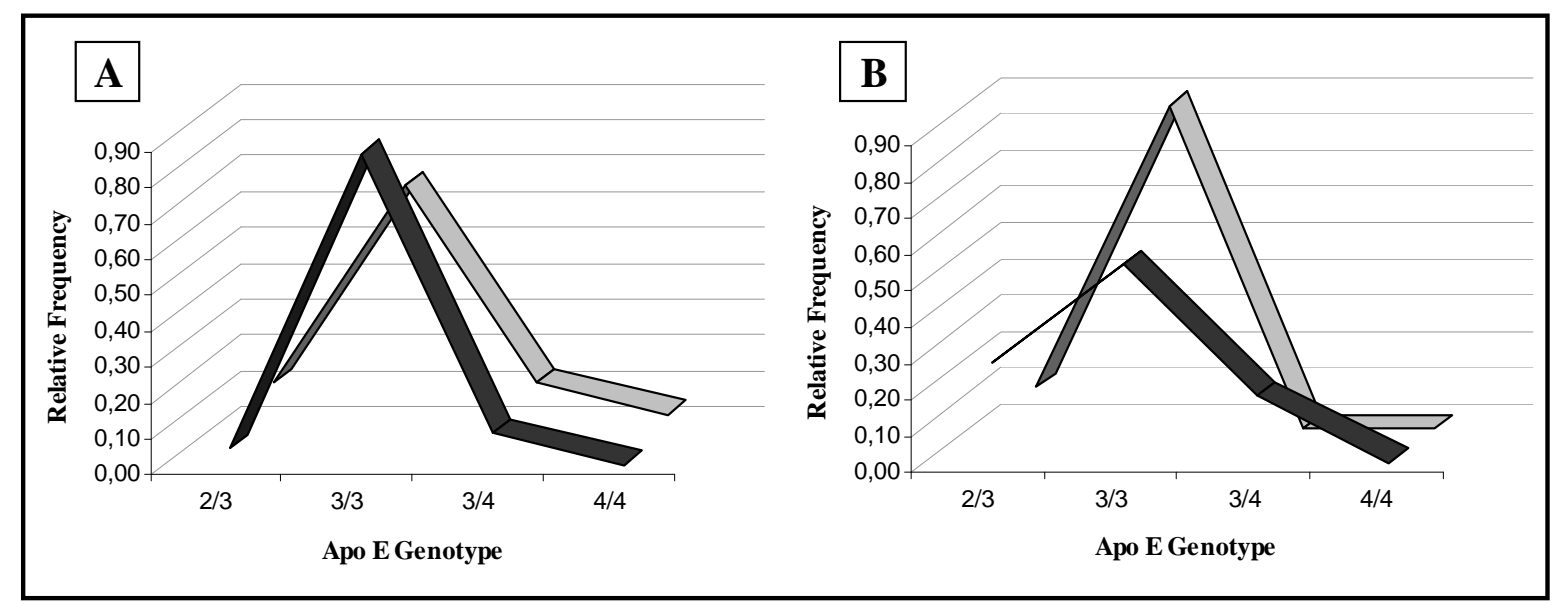

Figure 1 - Distribution of apo E genotypes by gender in both control groups. A - Lisbon; B Ponta Delgada. Black lines - females; gray lines - males

Table 3 - Body mass index, blood pressure and serum lipid concentrations, according to apo E genotypes subgroups for Lisbon and Ponta Delgada groups.

\begin{tabular}{l|ccc|ccc|ccc}
\hline & \multicolumn{3}{c}{ Lisbon } & \multicolumn{3}{c}{ Ponta Delgada } \\
Parameters & \multicolumn{3}{c}{ Control } & \multicolumn{3}{c}{ Control } & \multicolumn{3}{c}{ Patients } \\
\cline { 2 - 9 } & E2 & E3 & E4 & E2 & E3 & E4 & E2 & E3 & E4 \\
& $(\mathrm{n}=5)$ & $(\mathrm{n}=54)$ & $(\mathrm{n}=8)$ & $(\mathrm{n}=8)$ & $(\mathrm{n}=28)$ & $(\mathrm{n}=4)$ & $(\mathrm{n}=5)$ & $(\mathrm{n}=31)$ & $(\mathrm{n}=4)$ \\
\hline BMI $\left(\mathrm{kg} / \mathrm{m}^{2}\right)$ & $30.1 \pm 2.9$ & $26.8 \pm 4.3$ & $28.6 \pm 7.6$ & $26.1 \pm 4.1$ & $26.4 \pm 3.4^{\mathrm{c}}$ & $24.3 \pm 2.6$ & $29.1 \pm 4.2$ & $30.6 \pm$ & $28.5 \pm 6.9$ \\
Blood Pressure $(\mathrm{mm}$ & & & & & & & & & \\
Systolic BP & $137 \pm 4$ & $129 \pm 21$ & $150 \pm 22$ & $123 \pm 17$ & $130 \pm 18^{\mathrm{c}}$ & $135 \pm 21$ & $144 \pm 19$ & $146 \pm$ & $144 \pm 23$ \\
Diastolic BP & $86 \pm 4^{\mathrm{f}}$ & $79 \pm 12^{\mathrm{a}}$ & $85 \pm 14$ & $72 \pm 11^{\mathrm{b}, \mathrm{e}, \mathrm{f}}$ & $85 \pm 13^{\mathrm{a}, \mathrm{b}}$ & $79 \pm 14$ & $92 \pm 11^{\mathrm{e}}$ & $89 \pm 15$ & $86 \pm 5$ \\
Serum Lipids $(\mathrm{mg} / \mathrm{dl})$ & & & & & & & & & \\
Total Cholesterol & $193 \pm 37$ & $208 \pm 35$ & $209 \pm 31$ & $194 \pm 31$ & $218 \pm 32$ & $215 \pm 38$ & $190 \pm 33$ & $195 \pm 41$ & $168 \pm 36$ \\
HDL-Cholesterol & $52 \pm 9$ & $60 \pm 12$ & $55 \pm 12$ & $58 \pm 10$ & $55 \pm 14^{\mathrm{c}}$ & $65 \pm 11^{\mathrm{d}}$ & $47 \pm 12$ & $43 \pm 8^{\mathrm{c}}$ & $37 \pm 0.5^{\mathrm{d}}$ \\
LDL-Cholesterol & $120 \pm 32$ & $123 \pm 28^{\mathrm{a}}$ & $133 \pm 23$ & $111 \pm 25^{\mathrm{b}}$ & $139 \pm 31^{\mathrm{a}, \mathrm{b}, \mathrm{c}}$ & $133 \pm 33$ & $95 \pm 37$ & $118 \pm$ & $104 \pm 39$ \\
Triglycerides & $111 \pm 49$ & $99 \pm 39$ & $102 \pm 22$ & $94 \pm 21^{\mathrm{e}}$ & $106 \pm 39^{\mathrm{c}}$ & $84 \pm 36$ & $160 \pm 70^{\mathrm{e}}$ & $159 \pm$ & $135 \pm 51$ \\
\hline \hline
\end{tabular}

Data are presented as mean \pm standard deviation. Values in each row sharing the same superscript are significantly different (t-test, $p<0.05)$.

Comparing the control groups from the two cities, the E3 subgroup from Ponta Delgada had higher diastolic blood pressure and LDL-cholesterol contents than its counterpart from Lisbon and the E2 subgroup showed higher values of diastolic blood pressure in Lisbon (Table 3). No discrepancies were observed for the studied parameters among the Lisbon subgroups (Table 3). For the control subjects from Ponta Delgada, E3 subgroup presented higher values of diastolic blood pressure and LDL-cholesterol and also approached statistical significance for total 
cholesterol (t-test, $p=0.067$ ) relative to E2 subgroup (Table 3). Additionally, in Ponta Delgada E3 subgroups, values for total, HDL- and LDL-cholesterol were higher in control subjects in comparison to patients; while systolic blood pressure and triglycerides levels were lower (Table 3). For E4 subgroups, HDL-cholesterol concentration was enhanced in control subjects in comparison to patients (Table 3). Patients from the E2 subgroup presented higher levels of diastolic blood pressure and triglycerides than their counterpart (Table 3).

\section{DISCUSSION}

The common alleles $\varepsilon 2, \varepsilon 3$ and $\varepsilon 4$ for apolipoprotein $\mathrm{E}$ are thought to confer risk information for disease due to their possible association with interindividual variation of the lipid profile in both healthy and pathological populations (Stengard et al., 1996).

In the present study, the Hardy-Weinberg equilibrium for apo $\mathrm{E}$ was in accordance with findings by Schiele et al. (2000) for Lisbon population and was observed for the first time for Ponta Delgada city from the Azores' Archipelago. The Hardy-Weinberg law plays an important role concerning population genetics and often serves as a basis for genetic inference (Guo and Thompson, 1992). In several population studies, the gene frequencies measured for apo $\mathrm{E}$ range from 0.077 to 0.170 for $\varepsilon 2$, from 0.720 to 0.783 for $\varepsilon 3$, and from 0.110 to 0.175 for $\varepsilon 4$ (Ehnholm et al., 1986; Braeckman et al., 1996; Ballantyne et al., 2000; Schiele et al., 2000). The frequencies of apo E alleles observed in our study in Lisbon and Ponta Delgada cities were not far from those for other European populations (Schiele et al., 2000), but the $\varepsilon 4$ allele frequency was lower. It is known that the $\varepsilon 4$ frequency in Europe is distributed along a decreasing north/south gradient (Siest et al., 1995a; Siest et al., 1995b; Boer et al., 1997; Schiele et al., 2000). In comparison to the results of the ApoEurope Project (Schiele et al., 2000) and being aware of the huge difference in samples size, the relative allelic frequencies found by us for $\varepsilon 2$ and $\varepsilon 4$ in Lisbon population were inferior (0.037 versus 0.063 and 0.067 versus 0.097$)$ and for $\varepsilon 3$ was superior ( 0.896 versus 0.839 ). Anyway, through the present study, the $\varepsilon 3$ allele was once more validated as the most representative in a population (Mahley et al., 1984; Mahley, 1988).

Apolipoprotein E $\varepsilon 2 / \varepsilon 3$ heterozygoty may have a protective effect on the development of early atherosclerosis (Menzel et al., 1983) and the various apo $\mathrm{E}$ isoforms have been suggested to exert different antioxidant effects (Slooter et al., 2001). The lower $\varepsilon 2 / \varepsilon 3$ frequency observed in Lisbon in comparison to Ponta Delgada control subjects implies that any protective effect towards atherosclerosis could be limited in mainland relative to the island (Slooter et al., 2001). Furthermore, the rare high risk genotypes were not found in our study (except one $\varepsilon 4 / \varepsilon 4$ person), which agrees with studies on other populations (Stengard et al., 1995; Stengard et al., 1996; Boudreau et al., 1999).

In Ponta Delgada the genetic variability of apo E appeared to be lower than in Lisbon. The continuous departure of Portuguese subjects from the nine islands of Azores' to elsewhere constitutes a valid argument to take into consideration in this particular case. Migration processes can act as a possible confounding factor towards allelic frequencies interpretation (Stengard et al., 1995). As far as we know, besides the detachment from mainland, islands represent per se a powerful way of isolation, that might contribute to the apparently lower variability found in Ponta Delgada. It would be of great interest to determine and compare the apo $\mathrm{E}$ polymorphism in the other islands and such research is warranted in a near future.

In this study, the distribution of apo E genotypes within Ponta Delgada control group was different between genders. This result could be justified, mainly by the $\varepsilon 3 / \varepsilon 3$ genotype (the most common allelic profile), whose occurrence in Lisbon and Ponta Delgada pathological groups were higher in females. Furthermore, the genotypes proportion was not homogenous in the female gender across the three studied groups. These differences constitute novel findings, which are not in accordance with others (Boudreau et al., 1999) and require confirmation. The small sample size involved in this study could be considered as a potential misleading cause for this result (Novaro et al., 2003) or eventually a chance finding.

Besides the apo $\mathrm{E}$ allelic profile, other physiological and metabolic parameters such as hyperlipidemia, obesity, blood hypertension and also, lifestyles (e.g. smoking habits), are 
considered as major cardiovascular risk factors (Expert Panel, 2001). A relationship between apo $\mathrm{E}$ allele frequencies and known cardiocerebrovascular risk factors has been suggested (Siest et al., 1995b). The relative $\varepsilon 4$ allele frequency is elevated in populations with cardiovascular disease and also among those at high risk (Eggertsen et al., 1993; Stengard et al., 1995; Stengard et al., 1996). This allele was associated with high serum cholesterol levels in two European populations but less or not significant in two Asian populations (Utermann, 1987). In our study, any association between $\varepsilon 4$ allele and high serum cholesterol contents was not accomplished, in spite of a slight tendency in the Lisbon group. However, in a recent study conducted in Singapore, serum total cholesterol and LDL-cholesterol concentrations reached the highest levels in $\varepsilon 4$ carriers and the lowest in $\varepsilon 2$ carriers, and the reverse effect occurred in HDLcholesterol levels (Tan et al., 2003). Our findings could be justified by the lower allelic frequency of $\varepsilon 4$.

Portugal has the highest stroke mortality rate in Western Europe and cardiovascular diseases cause around $40 \%$ of death (World Health Organization, 2003). Obesity has become a world-wide epidemic (Bray and Tartaglia, 2000) and may play a role in disease occurrence (Carr and Brunzell, 2004), in particular in our country (Santos and Barros, 2003). Actuarial tables indicate that life expectancy is reduced when body mass index, the indicator of adiposity or fatness, is significantly increased above certain level (BMI above 30 $\mathrm{kg} / \mathrm{m}^{2}$ ), however associations between apo E genotypes and obesity have not been consistent and no consensus has been reached so far. For obese individuals, an overproduction of VLDL has been reported (Siest et al., 1995b). VLDL are catabolized in part through hepatic apo B/E receptors and knowing the high affinity of these receptors for binding E4-containing lipoproteins and their downregulation provided by the E4 isoform (Siest et al., 1995b), one could expect an accumulation of VLDL resulting in increased triglycerides levels in obese individuals. Alleles at loci coding either for the LDL receptor or for apo E should be included in the list of candidate genes determining susceptibility to metabolic abnormalities observed in the obese state, as suggested by Schreyer et al. (2003).
In the present study, the differences found for lipid parameters, body mass index and blood pressure according to apo E genotypes were not conclusive. Mainly for E2 and E3 genotype subgroups, these discrepancies could be related to the statistical power decurrent from a bigger sample size than for the other subgroups. Anyway, these discrepancies are in agreement with the strong evidence that weight loss reduces blood pressure and serum triglycerides levels, increases HDLcholesterol concentration and generally leads to a reduction in total and in LDL-cholesterol levels in serum (Expert Panel, 1998). Although not consensual, the apo $\mathrm{E} \varepsilon 3 / \varepsilon 4$ and $\varepsilon 4 / \varepsilon 4$ genotypes have been reported to be related to higher systolic blood pressure suggesting that apo $E$ polymorphism might be one cardiovascular risk factor per se (de Knijff et al., 1994; Uusitupa et al., 1994). As being so, the mechanisms responsible for hypertension in our subgroups might be complicated by comorbid conditions of obesity (Reckelhoff, 2001) and induced by various pressor agents, according to the National Institutes of Health (NIH, 1997). Thus, dislipidemia as well as hypertension conditions, whose incidence can increase with age (but with different expressions in females and males, as proposed by Reckelhoff, 2001), should be taken into consideration in further epidemiological studies for clarifying apo E polymorphism and atherosclerosis (and related cardiovascular diseases) relationship.

\section{Final remarks}

One limitation of this study should be acknowledged. Reduced samples size, especially in a genetic association study can potentially increase the risk of a false positive association. Further population cohort studies are needed to confirm and validate (or not) these findings. Whatever the future brings, apo $E$ genotype/phenotype determination in parallel with apo E plasma concentration are expected to yield useful clinical laboratory information (Siest et al., 1995a; Dreon and Peroutka, 2001). Thus, the estimation of apo E genotypes will need to become fast, economical, and technically undemanding in order to allow the investigation concerning apo $\mathrm{E}$ polymorphism and atherosclerosis widely available. 


\section{ACKNOWLEDGEMENTS}

This work forms part of the project "Markers of the prooxidant/antioxidant balance and characterization of the allelic profile of Apo $E$ in inhabitants of Lisbon and Ponta Delgada", supported by Fundação para a Ciência e a Tecnologia (POCTI/ESP/41008/2001), CBA (Centro de Biologia Ambiental) and Instituto de Investigação Científica Bento da Rocha Cabral. Paula Alexandra Lopes is grateful for a $\mathrm{PhD}$ fellowship (FCT/PRAXIS XXI/BD/21444/99). Authors are indebt to the National Health Institute Dr. Ricardo Jorge and all its technical staff for the support in the blood collection and in the determination of serum lipid parameters.

\section{RESUMO}

O principal objectivo deste estudo é o de pesquisar o efeito da insularidade nos polimorfismos da apolipoproteína (apo) E em indivíduos saudáveis do continente (Lisboa) e de Ponta Delgada (Ilha de S. Miguel, Arquipélago dos Açores). Adicionalmente, estudar a distribuição dos seus genótipos em doentes com aterosclerose da Ilha de S. Miguel. Em Lisboa, a distribuição dos genótipos da apo $E$ foi a seguinte: $\varepsilon 3 / \varepsilon 3>\varepsilon 3 / \varepsilon 4>$ $\varepsilon 2 / \varepsilon 3>\varepsilon 4 / \varepsilon 4$, ao passo que em Ponta Delgada e independentemente da condição fisiológica foi: $\varepsilon 3 / \varepsilon 3>\varepsilon 2 / \varepsilon 3>\varepsilon 3 / \varepsilon 4$. Distintas frequências genotípicas foram observadas entre homens e mulheres no grupo saudável de Ponta Delgada. O índice de massa corporal, hipertensão arterial e perfil lipídico, factores de risco associados ao processo aterosclerótico, revelaram algumas diferenças quando avaliados em função dos grupos alélicos. Neste estudo, os genótipos de risco da apo $\mathrm{E}, \varepsilon 2 / \varepsilon 2$ e $\varepsilon 2 / \varepsilon 4$, não foram contabilizados. Curiosamente a proporção dos genótipos nas mulheres foi heterogénea nos 3 grupos estudados.

\section{REFERENCES}

Andreassi, M. G. (2003), Coronary atherosclerosis and somatic mutations: an overview of the contributive factors for oxidative DNA damage. Mut. Res., 543, $67-86$.
Ballantyne, C. M.; Herd, J. A.; Stein, E. A.; Ferlic, L. L.; Dunn, J. K.; Gotto, A. M. and Marian, A. J. (2000), Apolipoprotein E genotypes and response of plasma lipids and progression-regression of coronary atherosclerosis to lipid lowering drug therapy. J. Am. Coll. Cardiol., 36, 1572-1578.

Ballantyne, F. C.; Clarck, R. S.; Simpson, H. S. and Ballantyne, D. (1982), HDL and LDL subfractions in myocardial infarction in control subjects. Metabol., 31, 433-437.

Bhakdi, S. (2003), An hypothesis for the immunopathogenesis of atherosclerosis. Clin. Nephrol., 60, S49-S52.

Boer, J. M. A.; Ehnholm, C.; Menzel, H.-J.; Havekes, L. M.; Rosseneu, M.; O’Reilly, D. StJ. and Tiret, L. (1997), Interactions between lifestyle-related factors and the apo E polymorphism on plasma lipids and apolipoproteins - the EARS study. Arterioscler. Thromb. Vasc. Biol., 17, 1675-1681.

Boudreau, D. A.; Scheer, W. D.; Malcom, G. T.; Mulvad, G.; Pederson, H. S. and Jul, E. (1999), Apolipoprotein E and atherosclerosis in Greenland Inuit. Atheroscler., 145, 207-219.

Braeckman, L.; De Bacquer, D.; Rosseneu, M. and De Backer, G. (1996), Apolipoprotein E polymorphism in middle-aged Belgian men: phenotype distribution and relation to serum lipids and lipoproteins. Atheroscler., 120, 67-73.

Bray, G. A. and Tartaglia, L. A. (2000), Medicinal strategies in the treatment of obesity. Nature, 404, 672-677.

Carr, M. C. and Brunzell, J. D. (2004), Abdominal obesity and dyslipidemia in the metabolic syndrome: importance of type 2 diabetes and familial combined hyperlipidemia in coronary artery disease risk. $J$. Clin. Endocrinol. Metabol., 89, 2601-2607.

de Knijff, P.; Boomsma, D. I.; Feskens, E. J.; Jespersen, J.; Johansen, L. G.; Kromhout, D. and Havekes, L. M. (1994), Apolipoprotein E phenotype and blood pressure. Lancet, 343,1234-1235.

Dreon, D. M. and Peroutka, S. J. (2001), Medical utility of apoe allele determination in assessing the need for antioxidant therapy. Medical Hypotheses, 56, 357359.

Eggertsen, G.; Tegelman, R.; Ericsson, S.; Angelin, B. and Berglund, L. (1993), Apolipoprotein E polymorphism in a healthy Swedish population: variation of allele frequency with age and relation to serum lipid concentrations. Clin. Chem., 39, 21252129.

Ehnholm, C.; Lukka, M.; Kuusi, T.; Nikkilä, E. and Utermann, G. (1986), Apolipoprotein E polymorphism in the Finnish population: gene frequencies and relation to lipoprotein concentrations. J. Lipid Res., 27, 227-235. 
Eichner, J. E.; Dunn, S. T.; Perveen, G.; Thompson, D. M.; Stewart, K. E. and Stroehla, B. C. (2002), Apolipoprotein E polymorphism and cardiovascular disease: a huge review. Am. J. Epidemiol., 155, 487495.

Expert Panel on Detection, Evaluation, and Treatment of High Blood Cholesterol in Adults (2001), Executive summary of the third report of the National Cholesterol education program (NCEP) expert panel on detection, evaluation and treatment of high blood cholesterol in adults (adult treatment panel III). JAMA, 285, 2486-2497.

Expert Panel on the Identification, Evaluation, and Treatment of Overweight in Adults (1998), Clinical guidelines on the identification, evaluation and treatment of overweight and obesity in adults: executive summary. Am. J. Clin. Nutr., 68, 899-917.

Friedewald, W. T.; Levy, R. I. and Fredrickson, D. S. (1972), Estimation of the concentration of lowdensity lipoprotein cholesterol in plasma, without use of the preparative ultracentrifuge. Clin. Chem., 18, 499-502.

Guo, S. W. and Thompson, E. A. (1992), Performing the exact test of Hardy-Weinberg proportion for multiple alleles. Biometrics, 48, 361-372.

Hagberg, J. M.; Wilund, K. R. and Ferrell, R. E. (2000), Apo E gene and gene-environment effects on plasma lipoprotein-lipid levels. Physiol. Genomics, 4,101108.

Hixson, J. E. and Vernier, D. T. (1990), Restriction isotyping of human apolipoprotein $\mathrm{E}$ by gene amplification and cleavage with Hha I. J. Lipid Res., 31, 545-548.

Hui, D. Y.; Innerarity, T. L. and Mahley, R. W. (1984), Defective hepatic lipoprotein receptor binding of $\beta$ very low density lipoproteins from type III hyperlipoproteinemic patients. Importance of apolipoprotein E. J. Biol. Chem., 259, 860-869.

Leon, A. S.; Togashi, K.; Rankinen, T.; Després, J. P.; Rao, D. C.; Skinner, J. S.; Wilmore, J. H. and Bouchard, C. (2004), Association of apolipoprotein E polymorphism with blood lipids and maximal oxygen uptake in the sedentary state and after exercise training in the HERITAGE family study. Metabol., 53, 108-116.

Lin, H.-P. and Kao, J.-T. (2003), Apolipoprotein $\varepsilon 2 / 3$ genotype and type III hyperlipoproteinemia among Taiwanese. Clin. Chim. Acta, 330, 173-178.

Mahley, R. W.; Innerarity, T. L.; Rall, S. C. Jr. and Weisgraber, K. H. (1984), Plasma lipoproteins: apolipoprotein structure and function. J. Lipid Res., 25, 1277-1294.

Mahley, R. W. (1988), Apolipoprotein E: cholesterol transport protein with expanding role in cell biology. Science, 240, 622-630.

Menzel, H. J.; Kladetzky, R. G. and Assmann, G. (1983), Apolipoprotein E polymorphism and coronary artery disease. Arterioscler., 3, 310-315.
Miller, S. A.; Dykes, D. D. and Polesky, H. F. (1988), A simple salting out procedure for extracting DNA from human nucleated cells. Nucl. Acids Res., 16,1215.

National Institutes of Health (1997), The sixth report of the Joint National Committee on Prevention, Detection, Evaluation, and Treatment of High Blood Pressure. NIH Publication, pp. 98-4080 .

Novaro, G. M.; Sachar, R.; Pearce, G. L.; Sprecher, D. L. and Griffin, B. P. (2003), Association between apolipoprotein $\mathrm{E}$ alleles and calcific vascular heart disease. Circulation, 108, 1804-1808.

Peroutka, S. J. and Dreon, D. M. (2000), The value of genotyping for apolipoprotein $\mathrm{E}$ alleles in relation to vitamin E supplementation. Eur. J. Pharmacol., 410, 161-163.

Rall, S. C. Jr.; Weisgraber, K. H. and Mahley, R. W. (1982), Human apolipoprotein E - the complete amino acid sequence. J. Biol. Chem., 257, 4171-4178.

Reckelhoff, J. F. (2001), Gender differences in the regulation of blood pressure. Hypertension, 37, 11991208.

Richard, P.; Thomas, G.; Zulueta, M. P.; De Gennes, J. L.; Thomas, M.; Cassaigne, A.; Bereziat, G. and Iron, A. (1994), Common and rare genotypes of human apolipoprotein $\mathrm{E}$ determined by specific restriction profiles of polymerase chain reaction-amplified DNA. Clin. Chem., 40, 24-29.

Roses, A. D. (1998), Alzheimer Diseases: a model of gene mutations and susceptibility polymorphisms for complex psychiatric diseases. Am. J. Med. Genet. (Neuropsychiatric Genetics), 81, 49-57.

Santos, A.-C. and Barros, H. (2003), Prevalence and determinants of obesity in an urban sample of Portuguese adults. Public Health, 117, 430-437.

Schiele, F.; de Bacquer, D.; Vincent-Viry, M.; Beisiegel, U.; Ehnholm, C.; Evans, A.; Kafatos, A.; Martins, M. C.; Sans, S.; Sass, C.; Visvikis, S.; de Backer, G. and Siest G. (2000), Apolipoprotein E serum concentration and polymorphism in six European Countries: the ApoEurope Project. Atheroscler., 152, 475-488.

Schreyer, S. A.; Lystig, T. C.; Vick, C. M. and LeBoeuf, R. C. (2003), Mice deficient in apolipoprotein $\mathrm{E}$ but not LDL receptors are resistant to accelerated atherosclerosis associated with obesity. Atheroscler., 171, 49-55.

Schwanke, C. H.; da Cruz, I. B.; Leal, N. F.; Scheibe, R.; Moriguchi, Y. and Moriguchi, E. H. (2002), Analysis of the association between apolipoprotein $\mathrm{E}$ polymorphism and cardiovascular risk factors in an elderly population with longevity. Arq. Bras. Cardiol., 78, 561-579.

Shea, T. B.; Rogers, E.; Ashline, D.; Ortiz, D. and Sheu, M.-S. (2002), Apolipoprotein E deficiency promotes increased oxidative stress and compensatory increases in antioxidants in brain tissue. Free Radic. Biol. Med., 33, 1115-1120. 
Siest, G.; Henny, J.; Galteau, M. M.; Schiele, F.; Steinmetz, J. and Visvikis, S. (1995b), Lipid and lipoprotein genetic variability: an important contribution from the french health examination centers. Clin. Biochem., 28, 31-38.

Siest, G.; Pillot, T.; Régis-Bailly, A.; Leininger-Muller, B.; Steinmetz, J.; Galteau, M. M. and Visvikis, S. (1995a), Apolipoprotein E: an important gene and protein to follow in laboratory medicine. Clin. Chem., 41, 1068-1086.

Slooter, A. J. C.; Bots, M. L.; Havekes, L. M.; Iglesias del Sol, A.; Cruts, M.; Grobbee, D. E.; Hofman, A.; Van Broeckhoven, C.; Witteman, J. C. M. and Van Duijn, C. M. (2001), Apolipoprotein E and carotid artery atherosclerosis - the Rotterdam study. Stroke, 32, 1947-1952.

Stengard, J. H.; Pekkanen, J.; Ehnholm, C.; Nissinen, A. and Sing, C. F. (1996), Genotypes with the apolipoprotein $\varepsilon 4$ allele are predictors of coronary heart disease mortality in a longitudinal study of elderly Finnish men. Hum. Genet., 97, 677-684.

Stengard, J. H.; Zerba, K. E.; Pekkanen, J.; Ehnholm, C.; Nissinen, A. and Sing, C. F. (1995), Apolipoprotein E polymorphism predicts death from coronary heart disease in a longitudinal study of elderly Finnish men. Circulation, 91, 265-269.
Tan, C. E.; Tai, E. S.; Tan, C. S.; Chia, K. S.; Lee, J.; Chef, S. K. and Ordovas, J. M. (2003), Apo E polymorphism and lipid profile in three ethnic groups in the Singapore population. Atheroscler., 170, 253260.

Utermann, G. (1987), Apolipoprotein E polymorphism in health and disease. Am. Heart J., 113, 433-440.

Uusitupa, M.; Sarkkinen, E.; Kervinen, K. and Kesaniemi, Y. A. (1994), Apolipoprotein phenotype and blood pressure. Lancet, 343, 57.

Vincent-Viry, M.; Schiele, F.; Gueguen, R.; Bohnet, K.; Visvikis, S. and Siest, G. (1998), Biological variations and genetic reference values for apolipoprotein E serum concentrations: results from the STANISLAS cohort study. Clin. Chem., 44, 957965.

World Health Organization: Regional Office for Europe. Highlights on Health in Portugal (cited January 24 2003). Available from: http://www.euro.who.int/document/e62041.pdf.

Yokoyama, M. (2004), Oxidant stress and atherosclerosis. Curr. Opin. Pharmacol., 4,110-115. 